\title{
New roles for Fc receptors in neurodegeneration-the impact on Immunotherapy for Alzheimer's Disease
}

\author{
James P. Fuller ${ }^{1 *}$, Jeffrey B. Stavenhagen ${ }^{2}$ and Jessica L. Teeling ${ }^{1}$ \\ ' CNS Inflammation Group, Centre for Biological Sciences, University of Southampton, Southampton, UK \\ ${ }^{2}$ Biologics, H. Lundbeck A/S, Copenhagen, Denmark
}

\author{
Edited by: \\ Tibor Hortobágyi, University of \\ Debrecen, Hungary \\ Reviewed by: \\ Friederike Jönsson, Institut Pasteur, \\ France \\ Andreas Muhs, AC Immune, \\ Switzerland \\ *Correspondence: \\ James P. Fuller, Southampton \\ General Hospital, Mailpoint 840 \\ LD30, Tremona Road, Southampton \\ SO16 6YD, UK \\ e-mail: jpf1g11@soton.ac.uk
}

There are an estimated 18 million Alzheimer's disease (AD) sufferers worldwide and with no disease modifying treatment currently available, development of new therapies represents an enormous unmet clinical need. $A D$ is characterized by episodic memory loss followed by severe cognitive decline and is associated with many neuropathological changes. $A D$ is characterized by deposits of amyloid beta $(A \beta)$, neurofibrillary tangles, and neuroinflammation. Active immunization or passive immunization against $A \beta$ leads to the clearance of deposits in transgenic mice expressing human $A \beta$. This clearance is associated with reversal of associated cognitive deficits, but these results have not translated to humans, with both active and passive immunotherapy failing to improve memory loss. One explanation for these observations is that certain anti-A $\beta$ antibodies mediate damage to the cerebral vasculature limiting the top dose and potentially reducing efficacy. Fc gamma receptors ( $F c \gamma R)$ are a family of immunoglobulin-like receptors which bind to the Fc portion of IgG, and mediate the response of effector cells to immune complexes. Data from both mouse and human studies suggest that cross-linking Fc $\gamma R$ by therapeutic antibodies and the subsequent pro-inflammatory response mediates the vascular side effects seen following immunotherapy. Increasing evidence is emerging that Fc $\gamma R$ expression on CNS resident cells, including microglia and neurons, is increased during aging and functionally involved in the pathogenesis of age-related neurodegenerative diseases. Therefore, we propose that increased expression and ligation of FcyR in the CNS, either by endogenous IgG or therapeutic antibodies, has the potential to induce vascular damage and exacerbate neurodegeneration. To produce safe and effective immunotherapies for $A D$ and other neurodegenerative diseases it will be vital to understand the role of $F c \gamma R$ in the healthy and diseased brain. Here we review the literature on $\mathrm{Fc} \gamma \mathrm{R}$ expression, function and proposed roles in multiple age-related neurological diseases. Lessons can be learnt from therapeutic antibodies used for the treatment of cancer where antibodies have been engineered for optimal efficacy.

Keywords: Fc receptors, Alzheimer's Disease, immunotherapy, neuroinflammation, cytokines, ARIAs, autoantibodies

\section{INTRODUCTION}

Alzheimer's disease $(\mathrm{AD})$ is a devastating illness with a hugely detrimental effect on the quality of life of patients and their families. An estimated 18 million people worldwide suffer from $\mathrm{AD}$ and with an ever ageing population; the number of cases will increase. The currently approved treatments for $\mathrm{AD}$ are: inhibitors of the enzyme acetyl-cholinesterase, and Memantine which is a blocker of the neurotransmitter channel for glutamate (NMDA). Both these therapies are able to transiently improve cognition (Reisberg et al., 2003; Tariot et al., 2004), but no treatment is available that can modify disease progression. The increasing number of individuals suffering from $\mathrm{AD}$ and the burden placed on our healthcare services, makes developing effective $\mathrm{AD}$ therapeutics an urgent unmet clinical need.
$\mathrm{AD}$ patients initially present with episodic memory loss which is followed by severe cognitive decline, but pathological changes begin decades before clinical symptoms arise. The disease is characterized by a number of neuropathological changes including: the deposition of misfolded proteins in the brain as extra-cellular plaques and intracellular tangles, loss of synapses and neurons and an increased number and activation of glial cells. The primary component of plaques was identified as amyloid beta $(A \beta)$, a 39-43 amino acid peptide cleaved from the amyloid precursor protein (APP) (Masters et al., 1985; Allsop et al., 1988). Later it was discovered that mutations in the APP gene (Goate et al., 1991; Mullan et al., 1992), or increased copy number of APP found in Down's syndrome are associated with early onset AD pathology (Olson and Shaw, 1969). These histological and genetic findings formed the basis of the amyloid cascade hypothesis, which states 
that increased production or accumulation of $A \beta$ underlies the pathology of AD (Hardy and Selkoe, 2002). This hypothesis has driven most $\mathrm{AD}$ research in the last 20 years, resulting in the development of therapies targeted to reduce $A \beta$ production or clear $A \beta$ deposits from the brain.

Immunotherapy is one strategy that has been developed to clear $\mathrm{A} \beta$ from the brains of $\mathrm{AD}$ patients, with a number of vaccines and monoclonal antibodies against $A \beta$ that have been tested in clinical trials. Despite early optimism from successful pre-clinical work, this approach has not translated into disease modifying therapies. In 2012 two phase III clinical trials for anti-A $\beta$ antibodies Bapineuzumab (AAB-001, ELN115727) and Solanezumab (EXPEDITION 1 and EXPEDITION 2) failed to meet primary clinical endpoints of improvement in cognition (Doody et al., 2014; Salloway et al., 2014). A major safety finding was that Bapineuzumab caused vascular side effects designated amyloid related imaging abnormalities (ARIAs). This led to the discontinuation of the $2 \mathrm{mg} / \mathrm{kg}$ dose, which may have decreased efficacy (Salloway et al., 2010). In spite of these disappointing clinical results interest in this form of therapy persists with second generation antibodies that are currently being tested in $\mathrm{AD}$ prevention trials.

The mechanism underlying the development of side effects is poorly understood, and only a limited number of studies have investigate if the effector function of the therapeutic antibodies is critical for efficacy. Fc gamma receptors (Fc $\gamma$ Rs) bind to the constant domain of IgG, and are expressed on a wide variety of cell types including CNS macrophages- microglia. Activation of $\mathrm{Fc} \gamma \mathrm{R}$ can result in a pro-inflammatory response including the release of cytokines and other mediators (Carbone et al., 2013). Experimental models of $\mathrm{AD}$ and observations from clinical trials have provided evidence that activating $\mathrm{Fc} \gamma \mathrm{Rs}$ may be responsible for the activation of microglia following immunotherapy, and the associated side effects (Wilcock et al., 2006; Adolfsson et al., 2012; Freeman et al., 2012). There are a number of inflammatory changes within the CNS during ageing, which are further affected by $\mathrm{AD}$, including increased expression of all $\mathrm{Fc} \gamma \mathrm{Rs}$ on microglial cells and/or perivascular macrophages (Peress et al., 1993; Cribbs et al., 2012). This is functionally relevant as increased expression of activating Fc $\gamma$ Rs on microglia could drive an exacerbated response to therapeutic antibodies, possibly explaining the side effects observed in the Bapineuzumab clinical trials.

This review will describe the emerging roles for specific Fc $\gamma$ Rs in the underlying pathology of neurodegeneration and the potential for $\mathrm{F} c \gamma \mathrm{R}$ mediated tissue damage in the CNS. This will be discussed in the context of immunotherapy for AD and the considerations that should be made before the development of next generation antibodies targeting CNS antigens.

\section{FC RECEPTORS}

Fc $\gamma$ Rs bind to the constant region of IgG and are expressed on the surface of a wide range of immune effector cells. Human Fc $\gamma$ Rs can be functionally divided into three classes: activating (Fc $\gamma$ RI, Fc $\gamma$ RIIa, Fc $\gamma$ RIIc, and Fc $\gamma$ RIIIa), inhibitory (Fc $\gamma$ RIIb) or gpi linked decoy (Fc $\gamma$ RIIIb). There are a number of subclasses of human IgG (IgG1, IgG2, IgG3, and IgG4), each with varying affinity for the different Fc $\gamma$ Rs (Bruhns et al., 2009). There are four known murine Fc $\gamma$ Rs: activating (Fc $\gamma$ RI, Fc $\gamma$ RIII, and Fc $\gamma$ RIV) and inhibitory (Fc $\gamma$ RIIb) (Nimmerjahn and Ravetch, 2008). Similar to humans mice have 4 IgG subclasses (IgG1, IgG2a, IgG2b, and IgG3), but it should be noted that the nomenclature is different between species, and therefore human IgG1 is not homologous to murine $\operatorname{IgG} 1$, and its effector function is instead more similar to murine IgG2a.

Activating Fc receptors (with the exception of human Fc $\gamma$ RIIa) are associated with and signal through a separate Fc gamma chain ( $\mathrm{Fc} \gamma$ chain) which contains immune-tyrosine activation motifs (ITAMs). A common model used to study the roles of activating $\mathrm{Fc} \gamma \mathrm{Rs}$ in vivo are mice deficient for this Fc $\gamma$ chain, who lack expression of functional activating Fc $\gamma$ Rs. Activating Fc $\gamma R$ deficient mice show: decreased antibody mediated phagocytosis, abnormal platelet activation and an attenuate immune response to immune complexes (Takai et al., 1994). However, some of these effects may be mediated by other immune receptors, such as c-type lectins, which also depend on Fc $\gamma$ chain signaling (Geijtenbeek and Gringhuis, 2009). In contrast to activating Fc $\gamma$ receptors, the expression and therefore function of the inhibitory Fc $\gamma$ receptor (Fc $\gamma$ RIIb) is maintained. Human Fc $\gamma$ RIIa carries an intrinsic ITAM in its cytoplasmic domain. Ligation of IgG-immune complexes by activating Fc $\gamma$ Rs results in the crosslinking of the receptor and the phosphorylation of ITAMs in the cytoplasmic chain. This forms a binding site for the Spleen tyrosine kinase (Syk), which then activates downstream signaling cascades such as the PI3K pathway. Cellular calcium levels are increased and the cell becomes activated which can result in: proliferation, cytokine/chemokine release, phagocytosis and antigen presentation (Nimmerjahn and Ravetch, 2008). The inhibitory Fc $\gamma$ RIIb signals through an intrinsic cytoplasmic immuno tyrosine inhibitory motif (ITIM), cross-linking with an activating receptor results in ITIM phosphorylation leading to the inhibition of cellular activation (Nimmerjahn and Ravetch, 2008). The process of $\mathrm{Fc} \gamma \mathrm{R}$ mediated activation or inhibition of an effector cell is outlined in Figure 1.

The functional consequences of $\mathrm{Fc} \gamma \mathrm{R}$ ligation depends on the ratio of activating to inhibitory $\mathrm{Fc} \gamma \mathrm{Rs}$ expressed on the effector cell. Cells that have a high ratio of activating to inhibitory Fc $\gamma$ Rs are more prone to an uncontrolled immune response; this is demonstrated by Fc $\mathrm{RIIb}^{-/-}$mice which have an exacerbated response to autoantibodies inducing more tissue damage (Clynes et al., 1999; Yuasa et al., 1999). The response is also determined by the subclass; for example human IgG1 has higher affinity for activating Fc $\gamma$ Rs as compared to human IgG4, and will induce a more pro-inflammatory response (Bruhns et al., 2009). Activation of macrophages, including microglia, through $\mathrm{Fc} \gamma \mathrm{Rs}$ results in phagocytosis and polarization to an M2b phenotype which has attributes of both M1 and M2 macrophages. M2b macrophages release high levels of pro inflammatory cytokines such as TNF $\alpha$ and IL- $1 \beta$ as well as nitric oxide, all having potent tissue damaging properties (Mosser, 2003; Mantovani et al., 2004; Mosser and Edwards, 2008). In the context of immunotherapy anti-A $\beta$ antibodies reaching the CNS will bind to and coat plaques; this promotes activation of microglia through $\mathrm{Fc} \gamma \mathrm{Rs}$, resulting in the phagocytosis of the antibody-coated plaques and release of pro-inflammatory mediators. It should be noted that 

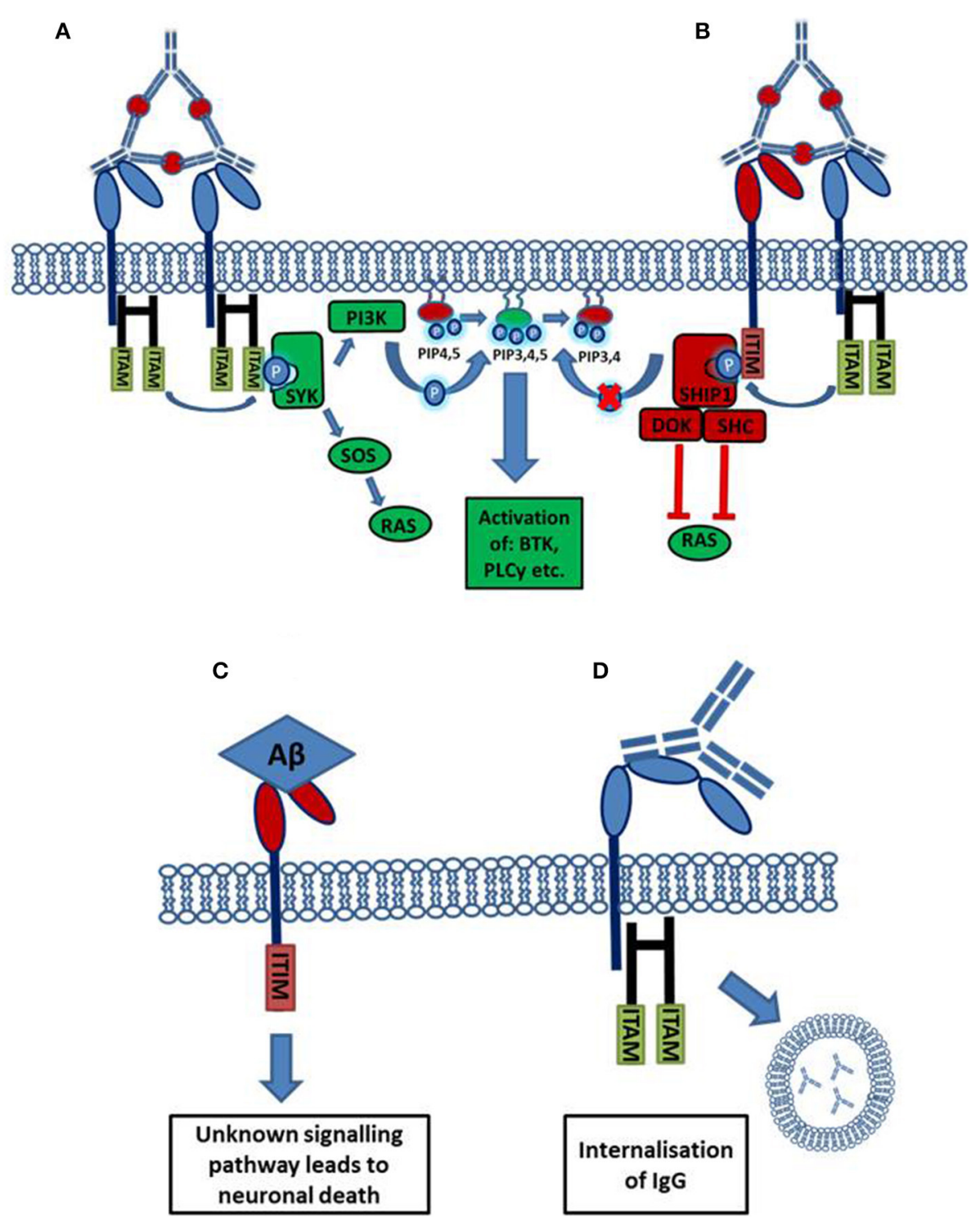

FIGURE 1 | Activation or inhibition of a cell by Fc receptor ligation of IgG immune complexes. (A) Cross linking of activating FcyRs by IgG immune complexes results in the phosphorylation of cytoplasmic ITAM motifs. This allows the recruitment of $\mathrm{SH} 2$ domain containing kinases of the SYK family. These kinases activate pathways such as the RAS and PI3K pathways resulting in increased cellular calcium and activation of the cell. (B) The cross linking of an inhibitory receptor to an activating receptor results in the phosphorylation of an ITIM, leading to the recruitment of the phosphatase
SHIP1. SHIP1 removes the 5'phopshate from $\mathrm{PiP}_{345}$ inhibiting downstream PI3K signaling, and also interacts with other adaptor proteins to inhibit other pathways. (C) $A \beta$ binds with high affinity to the inhibitory Fc $\gamma$ RIlb $\left(K_{D}=5.67 \times 10^{-8} \mathrm{M}\right)$. Through an unknown signaling pathway, the ligation of $A \beta$ causes the loss of Fc $\gamma R$ Rllb expressing neurons. (D) Fc $\gamma R I$ possesses an extra immunoglobulin like domain compared to other Fc $\gamma$ Rs. This allows the high affinity binding of monomeric lgG, ligation of monomeric lgG by Fc $\gamma \mathrm{RI}$ expressing neurons, facilitating antibody uptake. studies in Fc $\gamma \mathrm{R}$ deficient mice and application of antibodies with reduced or no effector function have shown that there are mechanisms of plaque removal independent of $\mathrm{Fc} \gamma \mathrm{R}$ binding (Bacskai et al., 2002; Das et al., 2003; Wilcock et al., 2006).

\section{HUMORAL IMMUNITY IN THE CNS \\ FCyR expression on CNS cells}

Although macrophages and microglia have been implicated as effector cells in the CNS following immunotherapy, recent data suggest a more broad expression pattern of FcRs in the CNS.
Increasing evidence suggest that multiple cell types within the CNS express Fc $\gamma$ Rs, and changes in expression patterns occur in response to different stimuli. Tables 1, 2 summarize the expression pattern and function of $\mathrm{Fc} \gamma \mathrm{Rs}$ on CNS cells in humans and mice respectively, under healthy and diseased conditions.

Human microglia express: Fc $\gamma$ RI, Fc $\gamma$ RIIa, Fc $\gamma$ RIIb, and Fc $\gamma$ RIIIa albeit at very low levels under normal conditions. The expression is increased on microglia in the CNS of patients with MS (Ulvestad et al., 1994), and a number of neurodegenerative conditions. In $\mathrm{AD}$ ramified microglia in the parenchyma, but 
Table 1 | Expression of Fc $\gamma$ Rs on murine CNS cells.

\begin{tabular}{|c|c|c|c|}
\hline Cell type & $\begin{array}{l}\text { FcyRs } \\
\text { expressed }\end{array}$ & $\begin{array}{l}\text { Conditions for } \\
\text { expression }\end{array}$ & References \\
\hline Microglia & 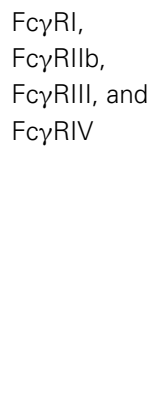 & $\begin{array}{l}\text { All } \uparrow: \text { Neurodegeneration } \\
\pm \text { systemic LPS, } \\
\text { immune complex } \\
\text { formation in retina } \\
\text { Fc } \gamma \text { RII/III } \uparrow: \text { Amyloid beta } \\
\text { immunotherapy or } \\
\text { arthus reaction in the } \\
\text { brain } \\
\text { Fc } \gamma \text { RI } \uparrow: \text { ageing, } \\
\text { especially in white } \\
\text { matter regions }\end{array}$ & $\begin{array}{l}\text { Wilcock et al., } \\
\text { 2004b; Lunnon } \\
\text { et al., 2011; Hart } \\
\text { et al., 2012; } \\
\text { Teeling et al., } \\
\text { 2012; Murinello } \\
\text { et al., } 2014\end{array}$ \\
\hline Neurons & $\begin{array}{l}\text { Fc } \gamma R I I b \\
\text { Fc } \gamma \text { RIV } \\
\text { Fc } \gamma \text { RII/III }\end{array}$ & $\begin{array}{l}\text { Fc } \gamma \text { RIIb } \uparrow: \text { A } \beta \text { treatment } \\
\text { Fc } \gamma \text { RIV } \uparrow: \text { APOE }-/- \\
\text { genetic background }\end{array}$ & $\begin{array}{l}\text { Kam et al., } 2013 \\
\text { Fernandez- } \\
\text { Vizarra et al., } \\
2012\end{array}$ \\
\hline Astrocytes & $F_{c \gamma} R I$ & $\begin{array}{l}\text { Fc } \gamma R \mid \uparrow: \text { increased CNS } \\
\lg G\end{array}$ & Li et al., 2008 \\
\hline $\begin{array}{l}\text { Oligo- } \\
\text { dendrocytes }\end{array}$ & Fc $\gamma$ chain & $\begin{array}{l}\text { Fc } \gamma \text { chain is expressed } \\
\text { by oligodendrocyte } \\
\text { precursor cells }\end{array}$ & $\begin{array}{l}\text { Nakahara et al., } \\
2003\end{array}$ \\
\hline $\begin{array}{l}\text { Endothelial } \\
\text { cells }\end{array}$ & FCRn & $\begin{array}{l}\text { FcRn constitutively } \\
\text { expressed on CNS } \\
\text { endothelium }\end{array}$ & $\begin{array}{l}\text { Deane et al., } \\
2005\end{array}$ \\
\hline
\end{tabular}

This table shows the expression patterns of FCyRs on different murine CNS cell types. The conditions in which up or down regulation of specific Fc $\gamma$ Rs has been observed have been recorded.

especially those associated with plaques express higher levels of: Fc $\gamma$ RI, Fc $\gamma$ RII, and Fc $\gamma$ RIII compared to age matched controls (Peress et al., 1993). Interestingly the expression of Fc $\gamma$ RI and $\mathrm{Fc} \gamma \mathrm{RIIb}$ are decreased on microglia of $\mathrm{AD}$ patients whose plaques were cleared by active immunotherapy (Zotova et al., 2013). Age related macular degeneration is associated with an increased number of CD45+ leukocytes expressing activating Fc $\gamma$ RIIa (and to a lesser extent inhibitory Fc $\gamma$ RIIb) at the choroidretinal epithelial cell interface (Murinello et al., 2014). Finally increased Fc $\gamma$ RI microglial expression is found in the CNS of patients with Parkinson's Disease (Orr et al., 2005). Murine microglia express all known Fc $\gamma$ Rs: Fc $\gamma$ RI, Fc $\gamma$ RIIb, Fc $\gamma$ RIII, and Fc $\gamma$ RIV. The expression of these receptors is increased in response to a number of different insults to the CNS. All four Fc $\gamma$ Rs are up regulated on microglia in response to experimental induced neurodegeneration (prion disease) and further upregulated by systemic inflammation, whilst up-regulation of Fc $\gamma$ RII/III has been observed in TG2576 APP mice (Wilcock et al., 2004b; Lunnon et al., 2011). We showed that type III hypersensitivity (or Arthus reaction) in the CNS (brain and retina) induces robust expression of: Fc $\gamma$ RI, Fc $\gamma$ RIIb, Fc $\gamma$ RIII, and Fc $\gamma$ RIV on microglia followed by a robust neuro-inflammatory response (Teeling et al., 2012; Murinello et al., 2014). Normal ageing is also associated with increased Fc $\gamma \mathrm{R}$ immuno-reactivity, and microglia especially those
Table 2 | Expression of FcyRs on human CNS cells.

\begin{tabular}{|c|c|c|c|}
\hline Cell type & $\begin{array}{l}\text { FcRs } \\
\text { expressed }\end{array}$ & Conditions for expression & References \\
\hline Microglia & $\begin{array}{l}\text { Fc } \gamma R \text { RI, } \\
\text { Fc } \gamma R I l a, \\
\text { Fc } \gamma R I l b, \\
\text { Fc } \gamma \text { RIIla }\end{array}$ & 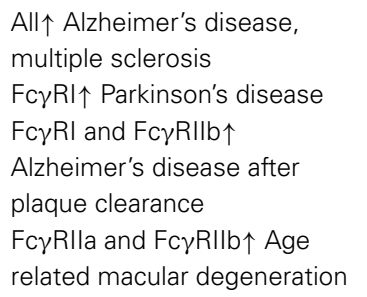 & $\begin{array}{l}\text { Peress et al., } \\
\text { 1993; Ulvestad } \\
\text { et al., 1994; Orr } \\
\text { et al., 2005; } \\
\text { Zotova et al., } \\
\text { 2013; Murinello } \\
\text { et al., } 2014\end{array}$ \\
\hline Neurons & $\begin{array}{l}F_{c} \gamma \mathrm{RI} \\
\mathrm{Fc}_{c} \mathrm{R} \text { RIlb }\end{array}$ & $\begin{array}{l}\text { FcRI Expressed constitutively } \\
\text { on sensory and motor } \\
\text { neurons } \\
\text { FcRIlb } \uparrow \text { Alzheimer's disease }\end{array}$ & $\begin{array}{l}\text { Mohamed et al., } \\
\text { 2002; Andoh and } \\
\text { Kuraishi, } 2004 \\
\text { Kam et al., } 2013\end{array}$ \\
\hline
\end{tabular}

This table shows the expression patterns of FCyRs on different human CNS cell types. The conditions in which up or down regulation of specific Fcy Rs has been observed have been recorded. There are a limited number of studies examining FCy $R$ expression for most human CNS cell types.

in white matter regions of the CNS, show elevated expression of Fc $\gamma$ RI (Hart et al., 2012).

The expression of Fc $\gamma$ Rs on neurons was once controversial, however a number of studies have now documented their expression on neurons both in vitro and in vivo. Human sensory and motor neurons express the high affinity Fc $\gamma$ RI which enable the cells to take up IgG from the surroundings (Mohamed et al., 2002; Andoh and Kuraishi, 2004). The inhibitory Fc $\gamma$ RIIb has been detected on healthy neurons in the hippocampus of both mice and humans. The expression of Fc $\gamma$ RIIb is increased on neurons in the $\mathrm{AD}$ brain, and also in response to treatment with A $\beta$ (Nakamura et al., 2007; Kam et al., 2013). Murine neurons have been found to express Fc $\gamma$ RII/III which mediate the uptake of therapeutic anti tau antibodies into neurons (Congdon et al., 2013). Finally neurons in the hippocampus of $\mathrm{APOE}^{-/-}$mice express Fc $\gamma$ RIV and signal in response to the higher levels of IgG in the CNS (Fernandez-Vizarra et al., 2012).

There are a limited number of studies investigating $\mathrm{Fc} \gamma \mathrm{R}$ expression on other CNS cell types. Fc $\gamma$ RI has been detected on astrocytes cultured in vitro, and also on rat astrocytes in vivo in response to $\mathrm{BBB}$ permeability changes (Li et al., 2008). There is also evidence that the $\mathrm{Fc} \gamma$ chain is required for differentiation of oligodendrocytes, however with other immunoreceptors that also signal through the Fc $\gamma$ chain it is not possible to conclude that Fc $\gamma$ Rs are required (Nakahara et al., 2003). Finally, murine CNS endothelial cells express the neonatal Fc receptor (FcRn). FcRn has been found to mediate the transport of therapeutic anti-A $\beta$ antibodies from the CNS into the periphery (Deane et al., 2005).

\section{Immunoglobulin G entry into the CNS}

Despite tight control by the BBB, it is apparent that small amounts of IgG enter the healthy brain and it has been estimated that $0.1 \%$ of circulating IgG enters the CNS via passive diffusion (Poduslo et al., 1994). However, this may be altered during ageing and/or disease, and associated changes in BBB integrity and 
interaction with FcRn. For example, under healthy conditions, IgG is removed from the CNS by an efficient process of reverse transcytosis across the BBB (Zhang and Pardridge, 2001), mediated by the neonatal transport receptor, FcRn (Schlachetzki et al., 2002; Deane et al., 2005).This transport of IgG is saturated at high levels of IgG, reducing the rate of IgG efflux. It is widely recognized that a functional blood-brain-barrier (BBB) limits passage of macromolecules and cells from the periphery and that disruption of the BBB by insults such as, ageing, stress and systemic inflammation, obesity is associated with an influx of serum proteins, including IgG (Lu et al., 2001; Diamond et al., 2006).Under these conditions the net influx of IgG would be increased, resulting in accumulation of IgG in the parenchyma, and around cerebral vessels.

\section{NEW ROLES FOR FC $\gamma$ RS IN NEURODEGENERATION}

There are emerging roles for different Fc $\gamma$ Rs in the underlying pathology of neurodegenerative disorders. As outlined in the previous section, increased expression of all Fc $\gamma$ Rs is consistently reported in human brain tissue of neuro-inflammatory and degenerative diseases including: Parkinson's (PD), AD, and Multiple sclerosis (Nyland et al., 1984; Peress et al., 1993; Ulvestad et al., 1994; Orr et al., 2005; Cribbs et al., 2012). There is evidence that ligation of specific Fc $\gamma$ Rs in the CNS by IgG and alternate ligands can promote neuroinflammation and/or enhance neurodegeneration.

\section{Auto antibodies}

Apart from elevated Fc $\gamma \mathrm{R}$, increased levels of total IgG in the CNS has also been reported in various neurodegenerative diseases, possibly as a result of an age-related increase in BBB permeability (Bouras et al., 2005). Serum from AD and PD patients are known to contain auto-antibodies to glutamatergic and dopaminergic neurons, which are selectively affected in $\mathrm{AD}$ and $\mathrm{PD}$ patients respectively. Furthermore, neurons of the substantia nigra (SN) from patients with Idiopathic cases of PD have been found to be immuno-reactive for IgG (Orr et al., 2005). IgG isolated from the sera of PD patients, injected into the brains of mice, specifically binds neurons in the SN. This binding induces neuroinflammation as measured by increased expression of CD11b, and loss of SN neurons (He et al., 2002). The use of Fc $\gamma$ chain ${ }^{-/-}$mice, which lack all activating $\mathrm{F} c \gamma \mathrm{Rs}$ or $\mathrm{F}(\mathrm{ab})_{2}$ fragments of PD IgG prevented these responses (He et al., 2002), demonstrating that an $\mathrm{Fc} \gamma \mathrm{R}$ mediated mechanism could drive neurodegeneration in PD. A similar role for Fc $\gamma$ Rs in the pathology of AD is described. Increased expression of Fc $\gamma$ Rs (Fc $\gamma$ RI, Fc $\gamma$ RII, and Fc $\gamma$ RIIIa) in disease affected areas of $\mathrm{AD}$ patients has been observed on both glial cells and neurons (Peress et al., 1993; Bouras et al., 2005). Application of serum-derived IgG from AD patients, containing neuron specific antibodies, into the forebrain of rats results in the selective reduction of cholinergic neurons, supporting the concept that in AD auto-reactive antibodies could in part drive neuronal loss (Engelhardt et al., 2000). The histological examination of brain tissue from AD patients provides further evidence for a detrimental role of these antibodies, as cholinergic neurons that stain positive for IgG also express markers of degeneration such as caspase 3 (D'Andrea, 2003).

\section{Neuronal Fcy Rs}

Evidence for a detrimental role of increased influx of serum derived IgG into the CNS was recently shown in ApoE deficient mice. This model is of interest to $\mathrm{AD}$ researchers because the ApoE4 allele is the largest genetic risk factor for sporadic AD (Strittmatter and Roses, 1995). ApoE deficient mice develop many neuropathological changes in common with $\mathrm{AD}$ including: increased blood brain barrier permeability, accumulation of intra neuronal $A \beta$, hyper phosphorylation of Tau and cognitive impairment (Fernandez-Vizarra et al., 2012). A critical role for FcyR was elegantly shown in this experimental model. When crossed onto Fc $\gamma$ chain deficient mice the double knock out animals have similar increased BBB permeability. However, they are protected from other neuropathological changes including: microgliosis, neuronal damage and cognitive impairment. Fc $\gamma$ chain deficient mice also do not express other immune receptors such as mincle or dectin 2(Geijtenbeek and Gringhuis, 2009), so this should be taken into account when analyzing this data. However specific knock-down of Fc $\gamma$ RIV with siRNA prevents similar effects of IgG on primary neurons in vitro. These results imply that it is the interaction between IgG in the brain and $\mathrm{Fc} \gamma \mathrm{R}$ expressing neurons that drive AD-like pathology in these mice. Neurons of AD patients and APP transgenic mice also express the inhibitory receptor FcyRIIb (Kam et al., 2013). FcyRIIb has a low affinity for monomeric IgG1 $\left(K_{\mathrm{D}}=\right.$ $\left.9.43 \times 10^{-6} \mathrm{M}\right)$, but binds with high affinity to $\mathrm{A} \beta\left(K_{\mathrm{D}}=5.67 \times\right.$ $\left.10^{-8} \mathrm{M}\right) . \mathrm{A} \beta$ is a potent inducer of neuronal apoptosis, and this effect is ameliorated in Fc $\gamma$ RIIb deficient neurons (Kam et al., 2013). It is not currently known if $A \beta$ signals through Fc $\gamma$ RIIb using the same signaling pathway as immune complexes. It will be important to understand if cross-linking of neuronal Fc $\gamma$ RIIb by immune complexes can induce the same effect.

\section{Protection from neurodegeneration in Fc $\gamma$ chain $-/-$ mice}

Our own studies have provided evidence that the Fc $\gamma$ chain also contributes to IgG-mediated inflammation and neuronal function. Formation of IgG immune complexes in the mouse brain (Teeling et al., 2012) or the mouse and human retina results in a transient, but robust neuroinflammatory response, that depends on activating Fc $\gamma$ Rs (Murinello et al., 2014). Further, using an experimental model of neurodegeneration, we show that Fc $\gamma$ Rs are expressed on microglia and further up-regulated following systemic inflammation. The latter is associated with increased production of pro-inflammatory cytokines, which is attenuated in Fc $\gamma$ chain deficient mice (Lunnon et al., 2011). The Fc $\gamma$ chain deficient background is also neuroprotective in other experimental models of neurodegenerative disease, including: ischemic stroke (KomineKobayashi et al., 2004) and synuclein-induced neurodegeneration following AAV transfer (Cao et al., 2010, 2012). These results indicate that the $\mathrm{Fc} \gamma$ chain is involved in neurodegeneration, however due to the loss of other immune receptors which signal through the Fcy chain it is currently not possible to conclude that only Fc $\gamma$ Rs are involved and further research using models for to test the role for specific $F c \gamma R$ is required. 


\section{The effects of soluble inflammatory mediators}

The ligation of therapeutic antibody coated plaques or autoantibody coated neurons by activating Fc $\gamma$ Rs may lead to the polarization of macrophages to a M2b phenotype and the production of a number of cytokines, chemokines, and inflammatory mediators. Receptors for a number of cytokines are expressed on CNS resident cells, so what is the effect of increasing the levels of these mediators on neurons?

Neuronal function is tightly regulated and a small change in homeostasis can be detrimental depending on the levels of cytokines produced. At physiological levels TNF $\alpha$ has important roles in regulating normal brain activity including regulation of synaptic scaling (Stellwagen and Malenka, 2006). Low levels of monomeric IgG in the brain $(0.2-20 \mathrm{ug} / \mathrm{ml})$ are observed under healthy conditions and induce low levels of TNF $\alpha$ via tonic signaling of Fc $\gamma$ RI expressed on microglia. Under these condition $\mathrm{TNF} \alpha$ is neuroprotective against excitotoxicity, but increasing levels of monomeric IgG abrogates this effect eventually becoming neurotoxic (Hulse et al., 2008). At higher levels $\mathrm{TNF} \alpha$, at least in vitro, is neurotoxic causing loss of cells by signaling through TNFR1 (Yang et al., 2002). Therefore increased $\mathrm{TNF} \alpha$ production as a result of excessive $\mathrm{Fc} \gamma \mathrm{R}$ ligation could be twofold: high levels could induce apoptosis of susceptible neurons or it could interfere with TNF $\alpha$ 's regulation of synaptic plasticity. IL- $1 \beta$ is also important for the function of neurons under physiological conditions. Normal concentrations of IL$1 \beta$ are essential for hippocampal long term potentiation (LTP), however higher pathological levels $(>10 \mathrm{ng} / \mathrm{ml})$ results in the inhibition of LTP (Katsuki et al., 1990; Bellinger et al., 1993; Ross et al., 2003). In vivo studies are sparse, but in vitro studies have provided further evidence of a critical role of $F c \gamma R$ in neuronal damage microglia co-cultured with dopaminergic neurons coated with IgG from the sera of PD patients, results in increased levels of pro-inflammatory cytokines ( $\mathrm{TNF} \alpha)$, reactive oxygen species synthesis, and the initiation of cell death in co-cultured neurons. The damage to neurons was shown to be dependent on NO production, as iNOS inhibitors but not cytokine blocking antibodies could inhibit neuronal death. This effect was shown to be Fc $\gamma$ chain-dependent as microglia from Fc $\gamma$ chain deficient mice fail to induce cytokine/ROS production or neuronal damage (Le et al., 2001). Recently it was shown that microglial activation in response to LPS or A $\beta$ could epigenetically regulate the expression of synaptic proteins, silencing neuroligin gene expression (Bie et al., 2014). The mediators produced by microglia which cause these effects are yet unknown, but it is possible that antibody mediated inflammation could also cause silencing neuroligin gene expression resulting in synapse loss. Therefore the increased production of: TNF $\alpha$, IL-1 $\beta$, NO or other inflammatory mediators by M2b polarized microglia could lead to impairment of neuronal function or exacerbation of neuronal/synapse loss in $\mathrm{AD}$ patients after treatment.

We propose that Fc $\gamma$ Rs may contribute to the pathology of neurodegenerative diseases through a number of mechanisms (summarized in Figure 2B). It is important to consider this when developing immunotherapies targeting CNS antigens. Targeting $\mathrm{A} \beta$ leads to changes in Fc $\gamma \mathrm{R}$ expression on CNS effector cells,

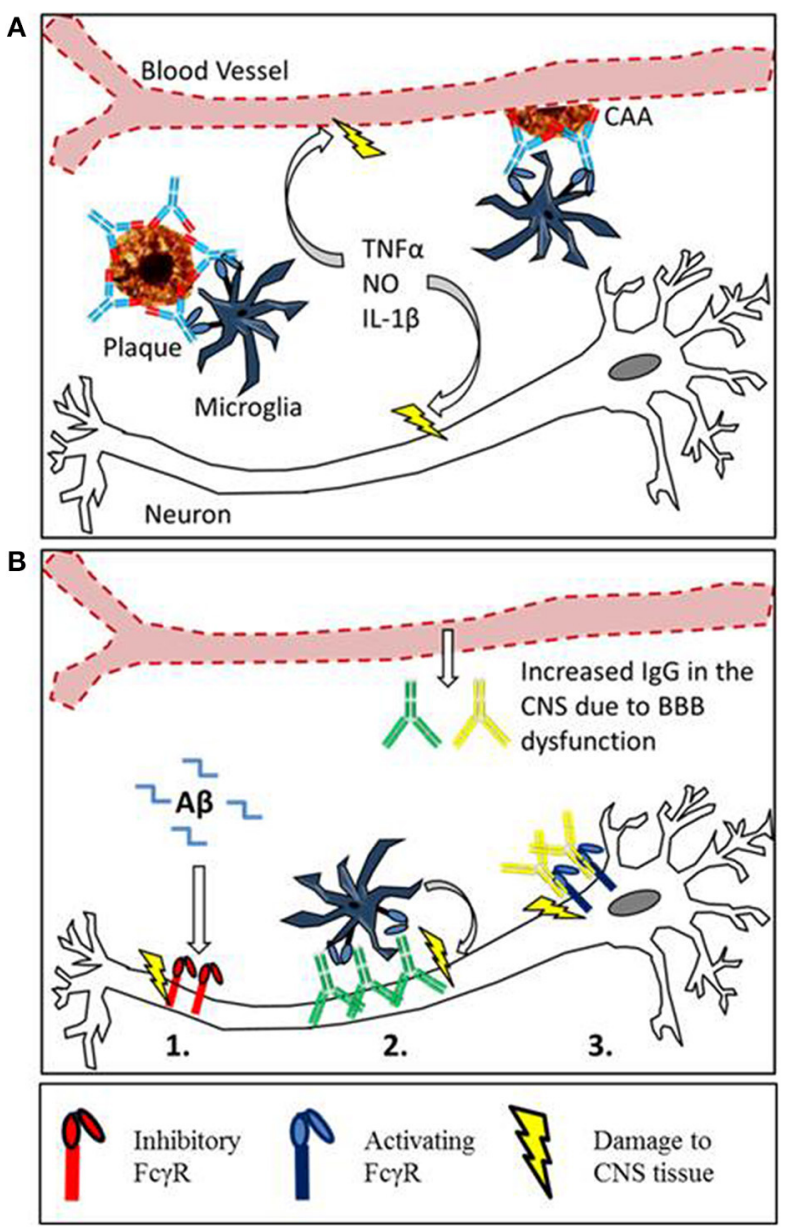

FIGURE 2 | Mechanisms of Fc receptor mediated tissue damage in the CNS. (A) The proposed mechanism for inflammatory tissue damage to CNS vasculature and neurons after Anti-A $\beta$ immunotherapy. Therapeutic antibodies penetrate the CNS and bind to deposits of $A \beta$ in the parenchyma and around the blood vessels. Microglia express activating $F c \gamma R$, and the antibody-A $\beta$ immune complexes cause cross linking and $F_{C} \gamma R$ activation. This results in a localized inflammatory response causing the vascular side effects observed in mice and humans. Furthermore soluble inflammatory mediators produced by this reaction may interfere with neuronal function or induce damage. (B) There is an emerging role for Fc $\gamma$ receptors in neurodegeneration, with 3 different proposed mechanisms of Fc receptor mediated damage to neurons. (1) Inhibitory Fc $\gamma$ receptor (FcyRIIb) expression has been detected on neurons, and FcRIlb binds $A \beta$ with high affinity. The ligation of $A \beta$ by neuronal FcRIlb results in neuronal death. (2) Autoantibodies against neurons are present in the sera of $A D$ patients and also observed binding to neurons. This could lead to Fc $\gamma R$ dependant neuronal loss through antibody dependent cellular cytotoxicity, caused by the ligation of activating $F_{c} \gamma$ receptors on microglia. (3) Activating $F_{c} \gamma R$ expression has been detected in certain models with neurodegenerative disease. Ligation of $\operatorname{lgG}$ by neuronal Fc receptors in mice results in neuronal loss.

if this alters the ratio of activating to inhibitory $\mathrm{Fc} \gamma \mathrm{R}$ it could exacerbate existing pathology. Furthermore immune complexes formed in the CNS may interact with $\mathrm{Fc} \gamma \mathrm{R}$ expressing cells, including neurons. At the moment the function of $F c \gamma R$ on neurons is unclear but it seems that their ligation can induce 
neuron loss. It will be important to understand the function and consequence of neuronal Fc $\gamma \mathrm{R}$ activation in the development of new immunotherapies.

\section{THE IMPORTANCE OF Fc $\gamma$ R IN DEVELOPING FUTURE IMMUNOTHERAPIES FOR ALZHEIMER'S DISEASE The role of $F c \gamma R$ s in the clearance of $A \beta$ and associated side effects}

The development of anti $A \beta$ immunotherapy has already been reviewed elsewhere (Schenk, 2002; Brody and Holtzman, 2008; Nitsch and Hock, 2008; Morgan, 2009; Lemere and Masliah, 2010), this section will instead focus on the side effects associated with immunotherapy and the putative role of Fc $\gamma$ Rs in plaque clearance. Passive immunization with anti- $\mathrm{A} \beta$ antibodies reduces amyloid deposition and reverses cognitive deficiencies in transgenic APP mice (Bard et al., 2000; DeMattos et al., 2001; Wilcock et al., 2004b). However the reduction in parenchymal amyloid is associated with increased deposition of $A \beta$ around the cerebral vasculature, and an increased incidence of cerebral micro-hemorrhage (Wilcock et al., 2004c). Data from clinical trials has shown that certain antibodies such as Bapineuzumab (hIgG1 anti $\mathrm{A} \beta$ ) are able to reduce or at least stabilize amyloid load in the brains of AD patients, measured by PET scan (Rinne et al., 2010; Salloway et al., 2014). However MRI scans of Bapineuzumab treated patients have also revealed similar vascular side effects to APP mice. Cerebral Micro-hemorrhage (ARIA$\mathrm{H}$ ) was observed at higher frequency in Bapineuzumab treated patients than placebo, whilst vasogenic edema (ARIA-E) was detected in $9.7 \%$ of patients treated with bapineuzumab and $0 \%$ in the placebo group (Salloway et al., 2010). Due to these side effects experienced by the patients, the top dose of bapineuzumab given in phase III was abandoned, potentially contributing to the lack of efficacy (Salloway et al., 2010). One mechanism for the clearance of plaques by anti $A \beta$ immunotherapy is through $\mathrm{F} c \gamma \mathrm{R}$ mediated phagocytosis of plaques by microglia; the involvement of microglia in clearance of $A \beta$ has been reviewed (Morgan, 2009). This phagocytic clearance seems to be a double edged sword, as the clearance of $A \beta$ is accompanied micro-hemorrhage and activation of microglia (Wilcock et al., 2004c). This activation takes the form of increased expression of markers such as CD45 and MHCII, and increased transcript levels of pro inflammatory cytokines and iNOS (Wilcock et al., 2004a,b, 2011). The proposed mechanism for microglial mediated damage to the vasculature and neurons is depicted in Figure 2A. Both microglial activation and micro-hemorrhage are prevented when anti- $\mathrm{A} \beta$ antibodies were deglycosylated or produced aglycosal reducing affinity for all Fc $\gamma$ Rs (Wilcock et al., 2006; Freeman et al., 2012). These findings have been translated into the development of Crenezumab where the selection of an antibody with lower affinity for all Fc $\gamma$ Rs has alleviated vascular side effects in humans (Adolfsson et al., 2012).

\section{Are "Primed" AD brains predisposed to an exacerbated response to immunotherapy?}

Neuro-inflammation in $\mathrm{AD}$ is characterized by an upregulation of immune regulatory receptors expressed on: microglia, astrocytes and perivascular cells as well as increased cytokine concentration in the brain (Peress et al., 1993; Wyss-Coray et al.,
2001). A causal role of inflammation in disease is supported by the recent genome wide association studies identifying a number of polymorphisms in immune receptors linked to higher risk of late onset $\mathrm{AD}$ in genes such as: Complement receptor 1 (Lambert et al., 2009), TREM2 (Guerreiro et al., 2013), HLA DR (Lambert et al., 2013) and CD33 (Hollingworth et al., 2011). We and others have shown that microglia, and perhaps vascular endothelial cells, are functionally altered adopting a "primed" phenotype with reduced threshold for innate immune activation (Lunnon et al., 2011; Puentener et al., 2012). Stimuli such as systemic bacterial infections can switch these cells into an aggressive phenotype, which may explain the exaggerated cognitive decline in $\mathrm{AD}$ patients with low grade systemic inflammation (Holmes et al., 2011). We also showed that the pro-inflammatory response is reduced in $\mathrm{F} \gamma \gamma$ chain deficient mice suggesting that these receptors or their signaling pathways play a role in microglial priming. Fc $\gamma \mathrm{R}$ expression in the healthy CNS is low, but altered expression of both activating and inhibitory Fc $\gamma \mathrm{Rs}$ as a result of ageing and/or neuroinflammation has been observed in both animal models (Lunnon et al., 2011; Hart et al., 2012; Teeling et al., 2012) and humans (Peress et al., 1993; Bouras et al., 2005; Cribbs et al., 2012). As the balance of activating and inhibitory $\mathrm{Fc} \gamma \mathrm{Rs}$ determines the effector function of the cell, higher expression of immune activating tyrosine motif (ITAM) bearing receptors in the CNS may exacerbate the response following ligation of therapeutic antibodies coating plaques. Neurons use a number of mechanisms to keep inflammatory response in the brain tightly regulated, preventing damage to the CNS- these mechanisms, include CD200 and fractalkine which have been reviewed previously (Hoarau et al., 2011). In AD it has been shown that these pathways are deregulated, and the inhibitory signal is reduced. These observations may have important implications for immunotherapy as primed microglia and/or endothelial cells may differentially respond to therapeutic antibodies. The loss of an inhibitory signal coupled with increased activating $\mathrm{F} c \gamma \mathrm{R}$ expression could drive an exacerbated response to plaques coated in antibodies. This could, at least partly, explain why patients receiving antibodies have experienced vascular damage. Furthermore this may lead to change in neural function as a result of increased production of pro-inflammatory mediators such as the cytokines IL-1 $\beta$, TNF $\alpha$ and nitric oxide (NO) (Le et al., 2001; Wilcock et al., 2011).

\section{CONCLUSIONS}

The clinical trials to date have shown that immunotherapy against $\mathrm{A} \beta$ is able to clear plaques from the brains of $\mathrm{AD}$ patients. However they have also highlighted the danger of immune activation within the CNS, which can result in damage to brain tissue. It appears that ligation of activating Fc $\gamma$ Rs by therapeutic antibodies causes damage to the vasculature of the CNS; we propose that immunotherapy could also impair the function of neurons through mechanisms outlined in Figure 2. We believe that we can learn lessons from cancer immunotherapy where the $\mathrm{Fc} \gamma \mathrm{R}$ affinity of monoclonal antibodies has been optimized by point mutations to improve efficacy. To a certain extent this has been started by AC Immune/Genentech whose new antibody Crenezumab (hIgG4) has lower Fc $\gamma \mathrm{R}$ affinity than previous 
antibodies. It may be possible to further improve by optimizing the relative affinity for specific $\mathrm{F} c \gamma$ Rs, allowing higher levels of plaque clearance with fewer side effects. It is clear that different Fc $\gamma$ Rs play a role in neurodegeneration by a number of mechanisms; however their normal function in the brain is not well understood. To allow the production of safe and effective CNS immunotherapies it is essential to understand the consequences of antibody accumulation and activation of Fc $\gamma$ Rs in the CNS. This would allow the selection the most appropriate antibody isotypes or mutants minimizing the risk of adverse events.

\section{REFERENCES}

Adolfsson, O., Pihlgren, M., Toni, N., Varisco, Y., Buccarello, A. L., Antoniello, K., et al. (2012). An effector-reduced anti- $\beta$-amyloid $(A \beta)$ antibody with unique $\mathrm{a} \beta$ binding properties promotes neuroprotection and glial engulfment of $\mathrm{A} \beta$. J. Neurosci. 32, 9677-9689. doi: 10.1523/JNEUROSCI.4742-11.2012

Allsop, D., Wong, C. W., Ikeda, S., Landon, M., Kidd, M., and Glenner, G. G. (1988). Evidence for the origin of cerebral amyloid in Alzheimer's disease drom A Beta protein precursor. Neuropathol. Appl. Neurobiol. 14, 254-255.

Andoh, T., and Kuraishi, Y. (2004). Primary sensory neurons express the high affinity IgG Fc gamma RI receptor and responds to IgG-antigen complex. J. Pharmacol. Sci. 94, 74P. doi: 10.1096/fj.02-1169fje

Bacskai, B. J., Kajdasz, S. T., McLellan, M. E., Games, D., Seubert, P., Schenk, D., et al. (2002). Non-Fc-mediated mechanisms are involved in clearance of amyloid-beta in vivo by immunotherapy. J. Neurosci. 22, 7873-7878.

Bard, F., Cannon, C., Barbour, R., Burke, R. L., Games, D., Grajeda, H., et al. (2000). Peripherally administered antibodies against amyloid beta-peptide enter the central nervous system and reduce pathology in a mouse model of Alzheimer disease. Nat. Med. 6, 916-919. doi: 10.1038/78682

Bellinger, F. P., Madamba, S., and Siggins, G. R. (1993). Interleukin 1 Beta inhibits synaptic strength and lon-term potentiation in the rat CA1 hippocampus. Brain Res. 628, 227-234. doi: 10.1016/0006-8993(93)90959-Q

Bie, B., Jiang, W., Yang, H., Xu, J. J., Brown, D. L., and Naguib, M. (2014). Epigentic suppresion of neuroligin 1 underlies amyloid induced memory deficiency. Nat. Neurosci. 17, 223-231. doi: 10.1038/nn.3618

Bouras, C., Riederer, B. M., Kovari, E., Hof, P. R., and Giannakopoulos, P. (2005). Humoral immunity in brain aging and Alzheimer's disease. Brain Res. Rev. 48, 477-487. doi: 10.1016/j.brainresrev.2004.09.009

Brody, D. L., and Holtzman, D. M. (2008). Active and passive immunotherapy for Neurodegenerative disorders. Annu. Rev. Neurosci. 31, 175-193. doi: 10.1146/annurev.neuro.31.060407.125529

Bruhns, P., Iannascoli, B., England, P., Mancardi, D. A., Fernandez, N., Jorieux, S., et al. (2009). Specificity and affinity of human Fc gamma receptors and their polymorphic variants for human IgG subclasses. Blood 113, 3716-3725. doi: 10.1182/blood-2008-09-179754

Cao, S., Standaert, D. G., and Harms, A. S. (2012). The gamma chain subunit of Fc receptors is required for alpha-synuclein-induced pro-inflammatory signaling in microglia. J. Neuroinflammation 9:259. doi: 10.1186/1742-2094-9-259

Cao, S., Theodore, S., and Standaert, D. G. (2010). Fc gamma receptors are required for NF-kappa B signaling, microglial activation and dopaminergic neurodegeneration in an AAV-synuclein mouse model of Parkinson's disease. Mol. Neurodegener. 5:42. doi: 10.1186/1750-1326-5-42

Carbone, F., Nencioni, A., Mach, F., Vuilleumier, N., and Montecucco, F. (2013). Evidence on the pathogenic role of auto-antibodies in acute cardiovascular diseases. Thromb. Haemost. 109, 854-868. doi: 10.1160/TH12-10-0768

Clynes, R., Maizes, J. S., Guinamard, R., Ono, M., Takai, T., and Ravetch, J. V. (1999). Modulation of immune complex-induced inflammation in vivo by the coordinate expression of activation and inhibitory Fc receptors. J. Exp. Med. 189, 179-185. doi: 10.1084/jem. 189.1.179

Congdon, E. E., Gu, J. P., Sait, H. B. R., and Sigurdsson, E. M. (2013). Antibody uptake into neurons occurs primarily via clathrin-dependent fc gamma receptor endocytosis and is a prerequisite for acute tau protein clearance. J. Biol. Chem. 288, 35452-35465. doi: 10.1074/jbc.M113.491001

Cribbs, D. H., Berchtold, N. C., Perreau, V., Coleman, P. D., Rogers, J., Tenner, A. J., et al. (2012). Extensive innate immune gene activation accompanies brain aging, increasing vulnerability to cognitive decline and neurodegeneration: a microarray study. J. Neuroinflammation 9:179. doi: 10.1186/1742-20949-179

D'Andrea, M. R. (2003). Evidence linking neuronal cell death to autoimmunity in Alzheimer's disease. Brain Res. 982, 19-30. doi: 10.1016/S0006-8993(03) 02881-6

Das, P., Howard, V., Loosbrock, N., Dickson, D., Murphy, M. P., and Golde, T. E. (2003). Amyloid-beta immunization effectively reduces amyloid deposition in FcR gamma(-/-) knock-out mice. J. Neurosci. 23, 8532-8538.

Deane, R., Sagare, A., Hamm, K., Parisi, M., LaRue, B., Guo, H., et al. (2005). IgG-assisted age-dependent clearance of Alzheimer's amyloid beta peptide by the blood-brain barrier neonatal Fc receptor. J. Neurosci. 25, 11495-11503. doi 10.1523/JNEUROSCI.3697-05.2005

DeMattos, R. B., Bales, K. R., Cummins, D. J., Dodart, J. C., Paul, S. M., and Holtzman, D. M. (2001). Peripheral anti-A beta antibody alters CNS and plasma A beta clearance and decreases brain A beta burden in a mouse model of Alzheimer's disease. Proc. Natl. Acad. Sci. U.S.A. 98, 8850-8855. doi: 10.1073/pnas. 151261398

Diamond, B., Kowal, C., Huerta, P. T., Aranow, C., Mackay, M., DeGiorgio, L. A., et al. (2006). "Immunity and acquired alterations in cognition and emotion: lessons from SLE," in Advances in Immunology, Vol. 89, ed F. W. Alt (New York, NY: Academic Press Inc.), 289-320.

Doody, R. S., Thomas, R. G., Farlow, M., Iwatsubo, T., Vellas, B., Joffe, S., et al. (2014). Phase 3 trials of solanezumab for mild-to-moderate Alzheimer's disease. N. Engl. J. Med. 370, 311-321. doi: 10.1056/NEJMoa13 12889

Engelhardt, J. I., Le, W. D., Siklos, L., Obal, I., Boda, K., and Appel, S. H. (2000). Stereotaxic injection of IgG from patients with Alzheimer disease initiates injury of cholinergic neurons of the basal forebrain. Arch. Neurol. 57, 681-686. doi: 10.1001/archneur.57.5.681

Fernandez-Vizarra, P., Lopez-Franco, O., Mallavia, B., Higuera-Matas, A., LopezParra, V., Ortiz-Munoz, G., et al. (2012). Immunoglobulin G Fc receptor deficiency prevents Alzheimer-like pathology and cognitive impairment in mice. Brain 135, 2826-2837. doi: 10.1093/brain/aws 195

Freeman, G. B., Brown, T. P., Wallace, K., and Bales, K. R. (2012). Chronic administration of an aglycosylated murine antibody of ponezumab does not worsen microhemorrhages in aged Tg2576 mice. Curr. Alzheimer Res. 9, 1059-1068. doi: $10.2174 / 156720512803569064$

Geijtenbeek, T. B. H., and Gringhuis, S. I. (2009). Signalling through C-type lectin receptors: shaping immune responses. Nat. Rev. Immunol. 9, 465-479. doi: $10.1038 /$ nri2569

Goate, A., Chartier-Harlin, M.-C., Mullan, M., Brown, J., Crawford, F., Fidani, L., et al. (1991). Segregation of a missense mutation in the amyloid precursor protein gene with familial Alzheimer's disease. Nature 349, 704-706. doi: $10.1038 / 349704 \mathrm{a} 0$

Guerreiro, R., Wojtas, A., Bras, J., Carrasquillo, M., Rogaeva, E., Majounie, E., et al. (2013). TREM2 variants in Alzheimer's disease. N. Engl. J. Med. 368, 117-127. doi: 10.1056/NEJMoa1211851

Hardy, J., and Selkoe, D. J. (2002). Medicine - The amyloid hypothesis of Alzheimer's disease: progress and problems on the road to therapeutics. Science 297, 353-356. doi: 10.1126/science.1072994

Hart, A. D., Wyttenbach, A., Perry, V. H., and Teeling, J. L. (2012). Age related changes in microglial phenotype vary between CNS regions: grey versus white matter differences. Brain Behav. Immun. 26, 754-765. doi: 10.1016/j.bbi.2011.11.006

He, Y., Le, W.-D., and Appel, S. H. (2002). Role of Fc $\gamma$ receptors in nigral cell injury induced by Parkinson disease immunoglobulin injection into mouse substantia nigra. Exp. Neurol. 176, 322-327. doi: 10.1006/exnr.2002.7946

Hoarau, J. J., Krejbich-Trotot, P., Jaffar-Bandjee, M. C., Das, T., Thon-Hon, G. V., Kumar, S., et al. (2011). Activation and control of CNS innate immune responses in health and diseases: a balancing act finely tuned by Neuroimmune Regulators (NIReg). CNS Neurol. Disord. Drug Targets 10, 25-43. doi: $10.2174 / 187152711794488601$

Hollingworth, P., Harold, D., Sims, R., Gerrish, A., Lambert, J.-C., Carrasquillo, M. M., et al. (2011). Common variants at ABCA7, MS4A6A/MS4A4E, EPHA1, $\mathrm{CD} 33$ and CD2AP are associated with Alzheimer's disease. Nat. Genet. 43, 429-435. doi: 10.1038/ng.803

Holmes, C., Cunningham, C., Zotova, E., Culliford, D., and Perry, V. H. (2011). Proinflammatory cytokines, sickness behavior, and Alzheimer disease. Neurology 77, 212-218. doi: 10.1212/WNL.0b013e318225ae07 
Hulse, R. E., Swenson, W. G., Kunkler, P. E., White, D. M., and Kraig, R. P. (2008). Monomeric IgG is neuroprotective via enhancing microglial recycling endocytosis and TNF-alpha. J. Neurosci. 28, 12199-12211. doi: 10.1523/JNEUROSCI.3856-08.2008

Kam, T.-I., Song, S., Gwon, Y., Park, H., Yan, J.-J., Im, I., et al. (2013). Fc $\gamma$ RIIb mediates amyloid- $\beta$ neurotoxicity and memory impairment in Alzheimer's disease. J. Clin. Invest. 123, 2791-2802. doi: 10.1172/JCI66827

Katsuki, H., Nakai, S., Hirai, Y., Akaji, K., Kiso, Y., and Satoh, M. (1990). Interleukin-1-Beta inhibits long-term potentiation in the CA3 region of mouse hippocampal slices. Eur. J. Pharmacol. 181, 323-326. doi: 10.1016/00142999(90)90099-R

Komine-Kobayashi, M., Chou, N., Mochizuki, H., Nakao, A., Mizuno, Y., and Urabe, T. (2004). Dual role of Fc $\gamma$ receptor in transient focal cerebral ischemia in mice. Stroke 35, 958-963. doi: 10.1161/01.STR.0000120321.30916.8E

Lambert, J. C., Heath, S., Even, G., Campion, D., Sleegers, K., Hiltunen, M., et al. (2009). Genome-wide association study identifies variants at CLU and CR1 associated with Alzheimer's disease. Nat. Genet. 41, 1094-1099. doi: $10.1038 / \mathrm{ng} .439$

Lambert, J.-C., Ibrahim-Verbaas, C. A., Harold, D., Naj, A. C., Sims, R., Bellenguez, C., et al. (2013). Meta-analysis of 74,046 individuals identifies 11 new susceptibility loci for Alzheimer's disease. Nat. Genet. 45, 1452-U206. doi: 10.1038/ng.2802

Le, W. D., Rowe, D., Xie, W. J., Ortiz, I., He, Y., and Appel, S. H. (2001). Microglial activation and dopaminergic cell injury: an in vitro model relevant to Parkinson's disease. J. Neurosci. 21, 8447-8455.

Lemere, C. A., and Masliah, E. (2010). Can Alzheimer disease be prevented by amyloid-beta immunotherapy? Nat. Rev. Neurol. 6, 108. doi: 10.1038/nrneurol.2009.219

Li, Y. N., Qin, X. J., Kuang, F., Wu, R., Duan, M. L., Ju, G., et al. (2008). Alterations of Fc gamma receptor I and Toll-like receptor 4 mediate the antiinflammatory actions of microglia and astrocytes after adrenaline-induced blood-brain barrier opening in rats. J. Neurosci. Res. 86, 3556-3565. doi: 10.1002/jnr.21810

Lu, J., Moochhala, S., Kaur, C., and Ling, E. A. (2001). Cellular inflammatory response associated with breakdown of the blood-brain barrier after closed head injury in rats. J. Neurotrauma 18, 399-408. doi: 10.1089/089771501750170976

Lunnon, K., Teeling, J. L., Tutt, A. L., Cragg, M. S., Glennie, M. J., and Perry, V. H. (2011). Systemic inflammation modulates Fc receptor expression on microglia during chronic neurodegeneration. J. Immunol. 186, 7215-7224. doi: 10.4049/jimmunol.0903833

Mantovani, A., Sica, A., Sozzani, S., Allavena, P., Vecchi, A., and Locati, M. (2004). The chemokine system in diverse forms of macrophage activation and polarization. Trends Immunol. 25, 677-686. doi: 10.1016/j.it.2004.09.015

Masters, C. L., Simms, G., Weinman, N. A., Multhaup, G., McDonald, B. L., and Beyreuther, K. (1985). Amyloid plaque core protein in alzheimerdisease and down syndrome. Proc. Natl. Acad. Sci. U.S.A. 82, 4245-4249. doi: 10.1073/pnas.82.12.4245

Mohamed, H. A., Mosier, D. R., Zou, L. L., Siklos, L., Alexianu, M. E., Engelhardt, J. I., et al. (2002). Immunoglobulin Fc gamma receptor promotes immunoglobulin uptake, immunoglobulin-mediated calcium increase, and neurotransmitter release in motor neurons. J. Neurosci. Res. 69, 110-116. doi: 10.1002/jnr.10271

Morgan, D. (2009). The role of microglia in antibody-mediated clearance of amyloid-Beta from the brain. CNS Neurol. Disord. Drug Targets 8, 7-15. doi: $10.2174 / 187152709787601821$

Mosser, D. M. (2003). The many faces of macrophage activation. J. Leukoc. Biol. 73, 209-212. doi: 10.1189/jlb.0602325

Mosser, D. M., and Edwards, J. P. (2008). Exploring the full spectrum of macrophage activation. Nat. Rev. Immunol. 8, 958-969. doi: 10.1038/nri2448

Mullan, M., Crawford, F., Axelman, K., Houlden, H., Lilius, L., Winblad, B., et al. (1992). A pathogenic mutation for probable Alzheimer's disease in the APP gene at the N terminus of beta amyloid. Nat. Genet. 1, 345-347. doi: 10.1038/ng08 92-345

Murinello, S., Mullins, R. F., Lotery, A. J., Perry, V. H., and Teeling, J. L. (2014). Fc gamma receptor upregulation is associated with immune complex inflammation in the mouse retina and early age-related macular degeneration. Invest. Ophthalmol. Vis. Sci. 55, 247-258. doi: 10.1167/iovs.13-11821

Nakahara, J., Tan-Takeuchi, K., Seiwa, C., Gotoh, M., Kaifu, T., Ujike, A., et al. (2003). Signaling via immunoglobulin Fc receptors induces oligodendrocyte precursor cell differentiation. Dev. Cell 4, 841-852. doi: 10.1016/S15345807(03)00155-2
Nakamura, K., Hirai, H., Torashima, T., Miyazaki, T., Tsurui, H., Xiu, Y., et al. (2007). CD3 and immunoglobulin G Fc receptor regulate cerebellar functions. Mol. Cell. Biol. 27, 5128-5134. doi: 10.1128/MCB.01072-06

Nimmerjahn, F., and Ravetch, J. V. (2008). Fcgamma receptors as regulators of immune responses. Nat. Rev. Immunol. 8, 34-47. doi: 10.1038/nri2206

Nitsch, R. M., and Hock, C. (2008). Targeting beta-amyloid pathology in Alzheimer's disease with A beta immunotherapy. Neurotherapeutics 5, 415-420. doi: 10.1016/j.nurt.2008.05.013

Nyland, H., Mork, S., and Matre, R. (1984). Fc gamma receptors in multiple sclerosis brains. Ann. N.Y. Acad. Sci. 436, 476-479. doi: 10.1111/j.17496632.1984.tb14823.x

Olson, M. I., and Shaw, C.-M. (1969). Presenile dementia and Alzheimer disease in mongolism. Brain 92, 147-156. doi: 10.1093/brain/92.1.147

Orr, C. F., Rowe, D. B., Mizuno, Y., Mori, H., and Halliday, G. M. (2005). A possible role for humoral immunity in the pathogenesis of Parkinson's disease. Brain 128, 2665-2674. doi: 10.1093/brain/awh625

Peress, N. S., Fleit, H. B., Perillo, E., Kuljis, R., and Pezzullo, C. (1993). Identifcation of Fc gamma RI, II and III on normal human brain ramified microglia in senile plaques in Alzheimer's disease. J. Neuroimmunol. 48, 71-80. doi: 10.1016/01655728(93)90060-C

Poduslo, J. F., Curran, G. L., and Berg, C. T. (1994). Macromolecular permeability across the blood-nerve and blood-brain barriers. Proc. Natl. Acad. Sci. U.S.A. 91, 5705-5709. doi: 10.1073/pnas.91.12.5705

Puentener, U., Booth, S. G., Perry, V. H., and Teeling, J. L. (2012). Long-term impact of systemic bacterial infection on the cerebral vasculature and microglia. J. Neuroinflammation 9:146. doi: 10.1186/1742-2094-9-146

Reisberg, B., Doody, R., Stoffler, A., Schmitt, F., Ferris, S., Mobius, H. J., et al. (2003). Memantine in moderate-to-severe Alzheimer's disease. N. Engl. J. Med. 348, 1333-1341. doi: 10.1056/NEJMoa013128

Rinne, J. O., Brooks, D. J., Rossor, M. N., Fox, N. C., Bullock, R., Klunk, W. E., et al. (2010). (11)C-PiB PET assessment of change in fibrillar amyloid-beta load in patients with Alzheimer's disease treated with bapineuzumab: a phase 2, doubleblind, placebo-controlled, ascending-dose study. Lancet Neurol. 9, 363-372. doi: 10.1016/S1474-4422(10)70043-0

Ross, F. M., Allan, S. M., Rothwell, N. J., and Verkhratsky, A. (2003). A dual role for interleukin-1 in LTP in mouse hippocampal slices. J. Neuroimmunol. 144, 61-67. doi: 10.1016/j.jneuroim.2003.08.030

Salloway, S., Sperling, R., Fox, N. C., Blennow, K., Klunk, W., Raskind, M., et al. (2014). Two phase 3 trials of bapineuzumab in mild-to-moderate Alzheimer's disease. N. Engl. J. Med. 370, 322-333. doi: 10.1056/NEJMoa1304839

Salloway, S. P., Black, R., Sperling, R., Fox, N., Gilman, S., Schenk, D., et al. (2010). A phase 2 multiple ascending dose trial of bapineuzumab in mild to moderate Alzheimer disease reply. Neurology 74, 2026-2027. doi: 10.1212/WNL.0b013e3181e03844

Schenk, D. (2002). Amyloid-beta immunotherapy for Alzheimer's disease: the end of the beginning. Nat. Rev. Neurosci. 3, 824-828. doi: 10.1038/nrn938

Schlachetzki, F., Zhu, C. N., and Pardridge, W. M. (2002). Expression of the neonatal Fc receptor (FcRn) at the blood-brain barrier. J. Neurochem. 81, 203-206. doi: 10.1046/j.1471-4159.2002.00840.x

Stellwagen, D., and Malenka, R. C. (2006). Synaptic scaling mediated by glial TNFalpha. Nature 440, 1054-1059. doi: 10.1038/nature04671

Strittmatter, W. J., and Roses, A. D. (1995). Apolipoprotein E and Alzheimer's disease. Proc. Natl. Acad. Sci. U.S.A. 92, 4725-4727. doi: 10.1073/pnas.92. 11.4725

Takai, T., Li, M., Sylvestre, D., Clynes, R., and Ravetch, J. V. (1994). FcR gammachain deletion results in pleiotropic effector cell defects. Cell 76, 519-529. doi: 10.1016/0092-8674(94)90115-5

Tariot, P. N., Farlow, M. R., Grossberg, G. T., Graham, S. M., McDonald, S., Gergel, I., et al. (2004). Memantine treatment in patients with moderate to severe Alzheimer disease already receiving donepezil: a randomized controlled trial. JAMA 291, 317-324. doi: 10.1001/jama.291.3.317

Teeling, J. L., Carare, R. O., Glennie, M. J., and Perry, V. H. (2012). Intracerebral immune complex formation induces inflammation in the brain that depends on Fc receptor interaction. Acta Neuropathol. 124, 479-490. doi: 10.1007/s00401012-0995-3

Ulvestad, E., Williams, K., Vedeler, C., Antel, J., Nyland, H., Mork, S., et al. (1994). Reactive microglia in multiple sclerosis lesions have an increased expression of receptors for the Fc part of IgG. J. Neurol. Sci. 121, 125-131. doi: 10.1016/0022510X(94)90340-9 
Wilcock, D. M., Alamed, J., Gottschall, P. E., Grimm, J., Rosenthal, A., Pons, J., et al. (2006). Deglycosylated anti-amyloid-beta antibodies eliminate cognitive deficits and reduce parenchymal amyloid with minimal vascular consequences in aged amyloid precursor protein transgenic mice. J. Neurosci. 26, 5340-5346. doi: 10.1523/JNEUROSCI.0695-06.2006

Wilcock, D. M., Munireddy, S. K., Rosenthal, A., Ugen, K. E., Gordon, M. N., and Morgan, D. (2004a). Microglial activation facilitates Abeta plaque removal following intracranial anti-Abeta antibody administration. Neurobiol. Dis. 15, 11-20. doi: 10.1016/j.nbd.2003.09.015

Wilcock, D. M., Rojiani, A., Rosenthal, A., Levkowitz, G., Subbarao, S., Alamed, J., et al. (2004b). Passive amyloid immunotherapy clears amyloid and transiently activates microglia in a transgenic mouse model of amyloid deposition. J. Neurosci. 24, 6144-6151. doi: 10.1523/JNEUROSCI.1090-04.2004

Wilcock, D. M., Rojiani, A., Rosenthal, A., Subbarao, S., Freeman, M. J., Gordon, M. N., et al. (2004c). Passive immunotherapy against Abeta in aged APPtransgenic mice reverses cognitive deficits and depletes parenchymal amyloid deposits in spite of increased vascular amyloid and microhemorrhage. J. Neuroinflammation 1, 24. doi: 10.1186/1742-2094-1-24

Wilcock, D. M., Zhao, Q., Morgan, D., Gordon, M. N., Everhart, A., Wilson, J. G., et al. (2011). Diverse inflammatory responses in transgenic mouse models of Alzheimer's disease and the effect of immunotherapy on these responses. ASN Neuro 3, 249-258. doi: 10.1042/AN20110018

Wyss-Coray, T., Lin, C., Yan, F. R., Yu, G. Q., Rohde, M., McConlogue, L., et al. (2001). TGF-beta 1 promotes microglial amyloid-beta clearance and reduces plaque burden in transgenic mice. Nat. Med. 7, 612-618. doi: 10.1038/87945

Yang, L., Lindholm, K., Konishi, Y., Li, R., and Shen, Y. (2002). Target depletion of distinct tumor necrosis factor receptor subtypes reveals hippocampal neuron death and survival through different signal transduction pathways. J. Neurosci. 22, 3025-3032.
Yuasa, T., Kubo, S., Yoshino, T., Ujike, A., Matsumura, K., Ono, M., et al. (1999). Deletion of Fc gamma receptor IIB renders H-2(b) mice susceptible to collagen-induced arthritis. J. Exp. Med. 189, 187-194. doi: 10.1084/jem. 189.1.187

Zhang, Y., and Pardridge, W. M. (2001). Mediated efflux of IgG molecules from brain to blood across the blood-brain barrier. J. Neuroimmunol. 114, 168-172. doi: 10.1016/S0165-5728(01)00242-9

Zotova, E., Bharambe, V., Cheaveau, M., Morgan, W., Holmes, C., Harris, S., et al. (2013). Inflammatory components in human Alzheimer's disease and after active amyloid-beta(42) immunization. Brain 136, 2677-2696. doi: 10.1093/brain/awt210

Conflict of Interest Statement: Jeff B. Stavenhagne is a full time employee of $\mathrm{H}$ lundbeck A/S. Jessica L. Teeling and James P. Fuller have received funding from $\mathrm{H}$ Lundbeck A/S

Received: 11 June 2014; accepted: 17 July 2014; published online: 21 August 2014. Citation: Fuller JP, Stavenhagen JB and Teeling JL (2014) New roles for Fc receptors in neurodegeneration-the impact on Immunotherapy for Alzheimer's Disease. Front. Neurosci. 8:235. doi: 10.3389/fnins.2014.00235

This article was submitted to Neurodegeneration, a section of the journal Frontiers in Neuroscience.

Copyright (C) 2014 Fuller, Stavenhagen and Teeling. This is an open-access article distributed under the terms of the Creative Commons Attribution License (CC BY). The use, distribution or reproduction in other forums is permitted, provided the original author(s) or licensor are credited and that the original publication in this journal is cited, in accordance with accepted academic practice. No use, distribution or reproduction is permitted which does not comply with these terms. 